\title{
Comparative Evaluation of the First-grade and Senior Medical School Students' Knowledge and Attitudes Toward Thoracic Surgery
}

\author{
İlk ve Son Sınıf Tıp Fakültesi Öğrencilerinin Gögüs Cerrahisi Hakkındaki \\ Bilgi ve Tutumlarının Karşılaştırmalı Değerlendirilmesi
}

\section{Cenk Balta}

Balıkesir University Faculty of Medicine, Department of Thoracic Surgery, Balıkesir, Turkey

\section{Abstract}

Objective: Comparison of the knowledge and attitudes of first and last year medical students about thoracic surgery.

Method: The answers of the five questionnaires which were directed to the first and last year medicine faculty students were evaluated comparatively. The first 4 questions were about the knowledge of thoracic surgery and the last question was about the wishes of thoracic surgery expertise in the future.

Results: There were 71 of first year and 68 of last year medicine students in this survey research. There were no correct answers to all of the first 4 questions. It was found that $15.49 \%$ of the first grade and $85.29 \%$ of the $6^{\text {th }}$ grade correctly knew the organs in the chest cavity. The first grade students could not give the correct answer to the question which was about the diseases of thoracic surgery, whereas only six participants in the sixth grade gave the correct answer. The students in both grades responded that the stage of the disease was important in the treatment of lung cancer. For the question evaluating the treatment methods of thoracic surgery, both student groups did not answer correctly. And both of student groups had inaccurate information on the treatment of rib fracture. While $29.57 \%$ of the first grade students considered to be a thoracic surgeon, none of the sixth grade students were willing to be a thoracic surgeon.

Conclusion: The knowledge of thoracic surgery is increasing at higher grades but it is still insufficient. The fact that the thoracic surgery is considered risky compared to other departments and the medical specialty exam scores which are effective in the decision on the specialization have a negative effect on medical students to choose thoracic surgery as a future career.

Keywords: Medical education, medical faculty, medical specialty, medical students, thoracic surgery

\section{Öz}

Amaç: Illk ve son sınıf tıp fakültesi öğrencilerinin göğüs cerrahisi hakkındaki bilgi ve tutumlarının karşılaştııımasıdır.

Yöntem: illk ve son sınıf tıp fakültesi öğrencilerine yöneltilen 5 anket. İlk 4 soru göğüs cerrahisi bilgisini sorgularken son soru gelecekte göğüs cerrahisi isteklerini irdeledi.

Bulgular: Ankete 1. sınıftan 71 ve 6. sınıftan 68 kişi katıldı. Illk 4 sorunun tümüne doğru cevap veren bulunmadı. Göğüs boşluğunda bulunan organları 1. sınıfların \%15,49'u, 6. sınıfların ise \%85,29'unun doğru olarak bildiği saptandı. İki grupta da en sık timüs ve yemek borusunun yerleşimi ile ilgili hatalar yapıldı. Göğüs cerrahisi alanına giren hastalıkların değerlendirildiği soru da birinci sınıflar doğru yanıt veremezken, 6 . sınıflardan sadece 6 kişi doğru yanıt verdi. Göğüs cerrahisi branşının tedavi yöntemlerinin değerlendirildiği soruyu iki grup da doğru olarak yanıtlayamazken iki grup öğrencileri büyük oranda kot fraktürü tedavisine yönelik yanlış bilgilere sahipti. Birinci sınıfların \%29,57'si $(n=21)$ göğüs cerrahisi alanında tıpta uzmanlık eğitimi düşünürken 6. sınıflardan göğüs cerrahisi uzmanı olmak isteyen saptanmadı.

Sonuç: Göğüs cerrahisi branşının bilinirliği tıp fakültesi öğrencilerinin sınıfı ilerledikçe artmakta fakat yine de yetersiz kalmaktadır. Göğüs cerrahisinin diğer bölümlere göre riskli kabul edilmesi ve uzmanlık seçiminde etkili olan tıbbi uzmanlık sınavı, tıp öğrencilerinin gelecekteki bir kariyer olarak göğüs cerrahisi seçimini olumsuz etkilemektedir.

Anahtar kelimeler: Göğüs cerrahisi, tıbbi uzmanlık, tıp eğitimi, tıp fakültesi, tıp öğrencisi

Address for Correspondence: Cenk Balta, Balıkesir University Faculty of Medicine, Department of Thoracic Surgery, Balıkesir, Turkey E-mail: drcenkbalta@gmail.com ORCID: orcid.org/0000-0002-4073-8101 Received: 10.08.2020 Accepted: 05.09.2020

Cite this article as: Balta C. Comparative Evaluation of the First-grade and Senior Medical School Students' Knowledge and Attitudes Toward Thoracic Surgery. Bagcilar Med Bull 2020;5(4):173-178

${ }^{\circledR}$ Copyright 2020 by the Health Sciences University Turkey, Bagcilar Training and Research Hospital Bagcilar Medical Bulletin published by Galenos Publishing House. 


\section{Introduction}

Since the introduction of technological advances to thoracic surgery (mechanical ventilation, double-lumen tube insertion, etc), this field of medicine has remained less recognized in the society and among healthcare workers due to the complex physiological and mechanical properties of the thoracic anatomy, name similarities, and its establishment as an independent specialty department recently. The access of most patients to thoracic surgeons occurs after they were referred by other physicians and medical staff. Therefore, the knowledge and awareness of thoracic surgery across physicians and healthcare professionals from other specialties of medicine are critical.

This survey study aimed to compare the awareness level of thoracic surgery among the first- and the senior-grade medical school students, who are the future physicians. By this study, we aimed to contribute to the awareness levels of medical students about thoracic surgery so that they could refer the right patient to a relevant clinic and we aimed to reveal the underlying reasons for medical students' disfavor of specializing in thoracic surgery, which became one of the least preferred fields of surgery for specialization, still displaying an ever-decreasing trend.

\section{Materials and Methods}

The study included volunteering first-grade and senior students attending the medical school of Balıkesir University in the 2019-2020 academic year. We developed a form comprising the informed consent and the questionnaire questions. We distributed the study form to eligible students to obtain their answers for the 5 questions in the questionnaire (Suppl 1). No demographic information other than age and sex and no information with the potential to reveal the identity of the participants were requested.

For comparisons, the participants were divided into two groups as the first-grade and senior students, which were named group 1 and group 2, respectively.

Our study was approved by the Local Ethics Committee (decision no: 2019/155). This study was conducted in compliance with the principles of the Declaration of Helsinki (version: B.10.4.ISM.4.06.68.48/184).

\section{Statistical Analysis}

Simple statistical analyses were performed using Microsoft Excel 2007. Further analyses were performed with SPSS (Statistical Package for the Social Sciences Version 24.0,
SPSS Inc. Sciences Version 22.0, SPSS Inc. Chicago, IL, USA). The categorical values were given as frequency (n) and percentage (\%) for descriptive analysis and the continuous data were expressed in mean \pm standard deviation (SD).

\section{Results}

A total of 139 students, comprising 71 (51.1\%) in group 1 and $68(48.9 \%)$ in group 2, participated in the survey. The mean age was $21.14 \pm 2.8$ years (mean $\pm \mathrm{SD}$ ) (minimummaximum $=17-27$ years) and $61(43.9 \%)$ participants were male and 78 (56.1\%) were female.

The first question asking the names of the organs in the thorax was answered correctly by $15.49 \%(n=11)$ and $85.29 \%$ $(\mathrm{n}=58)$ of the group 1 and group 2 participants, respectively (Table 1).

The second question asked the diseases included in the specialty area of thoracic surgery. Group 1 failed to answer this question correctly and only $8.82 \%(n=6)$ of the group 2 participants gave the precisely correct answers (Table 2 ).

The third question that asked the participants to mark the correct options was answered correctly by one person from group 1 (1.4\%) and 4 people from group 2 (5.88\%). The respondents most commonly answered that the stage of the disease was critical in the treatment of lung cancer (group $1=73.23 \%$, group $2=82.35 \%)$. While $48(67.6 \%)$ participants in group 1 answered that medical treatment of asthma and chronic obstructive pulmonary disease (COPD) was provided by thoracic surgeons, there were no participants in group 2 who gave this answer. While 18 participants $(25.35 \%)$ in group 1 correctly answered that the surgical procedures for lung cancer would accelerate disease progression, no participants from group 2 marked this option. Twenty-three (32.39\%) participants from group 1 and $28(41.17 \%)$ from group 2 answered that thoracic

\begin{tabular}{|c|c|c|}
\hline Question 1 & Group 1 n (\%) & Group 2 n (\%) \\
\hline Heart & 70 (98.59) & $68(100)$ \\
\hline Spleen & $63(88.73)$ & $68(100)$ \\
\hline Lung & $71(100)$ & $68(100)$ \\
\hline Esophagus & $39(54.92)$ & $66(97.05)$ \\
\hline Kidney & 69 (97.18) & $68(100)$ \\
\hline Thymus & $33(46.47)$ & $60(88.23)$ \\
\hline Stomach & $68(95.77)$ & $68(100)$ \\
\hline Liver & $59(83.09)$ & $68(100)$ \\
\hline Breast & 66 (92.95) & $68(100)$ \\
\hline
\end{tabular}


surgeons were authorized to perform sympathectomy for the treatment of regional hyperhidrosis. There were 39 (54.92\%) participants in group 1 and 6 (9.67\%) in group 2, who answered that the identification of lumps in the breast would require to be examined by a thoracic surgeon.

No participants in neither group gave the correct answers to all of the options of the fourth question that inquired the awareness of the types of operations performed by thoracic surgeons. Sixty-two (87.32\%) participants in group 1 and 30 (44.11\%) in group 2 failed to give the correct answer that the use of compression vests for the entire trunk had no place in the treatment of rib fractures. The fifth question inquired whether the participants would aim to specialize in thoracic surgery. Twenty-one (29.57\%) participants in group 1 answered yes to this question, while there were no participants who would like to specialize in thoracic surgery in group 2. Two people in each of the two groups left this question without comments. When the group 1 participants, who answered yes to this question, were asked the rationale for their preference, the most common option was "i am fond of surgery", marked by 18 (85.71\%) students. There were $48(67.60 \%)$ participants in group 1 and 66 (97.05\%) participants in group 2 stating that they would not prefer thoracic surgery for specialization. The reason for not preferring thoracic surgery was the preference for a "less risky specialty" $(\mathrm{n}=20)$ in group 1 , while the participants in group $2(\mathrm{n}=28)$ reported an "inclination to internal medicine specialty areas". The second most

Table 2. Responses of both groups through the question about the specialty area of thoracic surgery

\begin{tabular}{lll} 
Question 2 & $\begin{array}{l}\text { Group 1 } \\
\text { (n=71) }\end{array}$ & $\begin{array}{l}\text { Group 2 } \\
\text { (n=68) }\end{array}$ \\
\hline Pneumothorax & 46 & 64 \\
Lung cancer & 67 & 54 \\
Breast cancer & 37 & 0 \\
COPD & 58 & 10 \\
Pneumonia & 62 & 60 \\
Pulmonary hydatid cyst & 14 & 26 \\
Local hyperhidrosis & 14 & 26 \\
Thoracic traumas & 44 & 60 \\
Smoking cessation procedure & 28 & 8 \\
Cystic disease of breast & 32 & 2 \\
Esophagus cancer & 32 & 40 \\
Chest wall deformities & 55 & 56 \\
Diaphragm pathologies & 37 & 50 \\
Asthma & 45 & 4 \\
Thymus tumors & 29 & 50 \\
\hline
\end{tabular}

COPD: Chronic obstructive pulmonary disease common reason for disfavoring thoracic surgery was the option "i will decide based on my medical specialty exam (MSE/TUS) score" in both groups (group $1, \mathrm{n}=14$, group 2, $\mathrm{n}=22)$.

\section{Discussion}

Until the 1990s, when the thoracic surgery was defined as an independent functional medical specialty department in Turkey, thoracic surgery interventions were performed by surgeons from different disciplines, resulting in inappropriate awareness of this field of medicine (1). In this study, we conducted a survey across the first-grade and senior medical school students, aiming to compare the awareness about thoracic surgery between the groups and address the underlying reasons why or why not medical school students consider a specialization in thoracic surgery.

The first question inquired the organs in the thoracic cavity. The number of correct answers was low among first-grade medical students, classified as group 1 . This finding clearly indicates that human anatomy should be better taught in high school. The same question was answered correctly by $85.29 \%$ of the senior students, classified as group 2 . It was found out that $11.76 \%(n=8)$ and $2.94 \%(n=2)$ of the senior students did not know the location of the thymus and the esophagus, respectively, despite the education they received in the medical school. We can interpret this finding either by suggesting that the senior student participants did not pay enough attention to the survey questions or by critical inadequacies in medical education.

The second question inquired which subject matters were included in the field of the thoracic surgery specialty. The first-grade students failed to answer this question correctly and $8.82 \%(n=6)$ of the senior students answered this question precisely. The low rates of correct answers received from the first-grade students to this question can be explained by the Yildırım et al.'s (1) study, which reported that the term "thoracic surgery" was misunderstood as chest diseases or understood as referring to breast surgery by hospital staff other than physicians and ordinary individuals in the community. The low rates of correct answers received from the senior students suggest the likelihood of potential critical issues in the clinical practice to be experienced soon by these future physicians when they will need to perform in multidisciplinary teams or see patients in need of thoracic surgery interventions. 


\section{Supplement 1. Translation of the questionnaire}

1. Which of the following belongs in the rib cage?
- Spleen
- Lung
- Esophagus
- Kidney
- Thymus
- Stomach
- Liver
- Breast

\section{Which of the following diseases are in the field of thoracic surgery?}

- Pneumothorax

- Lung cancer

- Breast cancer

- Chronic obstructive pulmonary disease

- Pneumonia

- Pulmonary hydatid cyst

- Hyperhidrosis

- Chest traumas

- Smoking cessation

- Cystic diseases of breast

- Esophagus cancer

- Chest wall deformities

- Diaphragm pathologies

- Asthma

- Thymus tumors

\section{Which of the following is correct?}

- Diagnosis and treatment of asthma and chronic obstructive pulmonary disease should be managed by thoracic surgeons.

- Even in the early stage, any surgical procedure through to lung cancer will accelerate the progression of the disease.

- Thoracic sympathectomy surgery applied in palmar hyperhidrosis can be performed by thoracic surgeons.

- Surgery is the most appropriate treatment method of pulmonary hydatid cysts in adults.

- Primary spontaneous pneumothorax is more common in smokers, young, tall men. Pneumothorax follow-up and treatment is in the field of thoracic surgery.

- Self-examination of breasts is very important in early diagnosis. If a mass is suspected, it is necessary to consult a thoracic surgeon immediately.

- The stage of the disease is very important in the treatment of lung cancer. Depending on the stage of the disease, surgery and/or other oncological treatment methods can be chosen.

\section{Which of the thoracic surgery operations described below are incorrect?}

- Videothoracoscopy is the general name of thoracic surgeries performed with the help of a camera.

- Lobectomy is the surgical anatomic removal of one lobe of the lung.

- Mediastinoscopy is a bronchoscopy procedure performed to take samples from the mediastinal lymph nodes.

- Tube thoracostomy is the process of draining the air, blood or fluid that should not be in the pleural space.

- Thoracic sympathectomy is the surgical removal of the sympathetic nerves that provide sweating in especially regional hyperhidrosis of the hands and axilla.

- All chest corset is the method that provides thoracic stabilization in the treatment of rib fractures. 


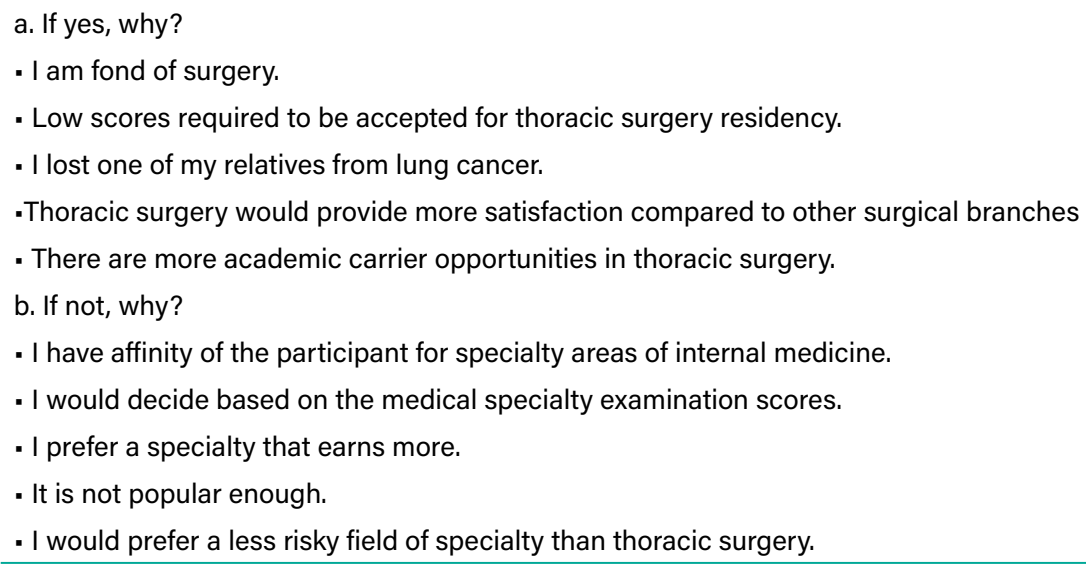

The majority of the participants from both groups answered the third question correctly, which inquired the thoracic surgery curriculum in general, covering the diseases mentioned in the second question. Most of the participants in either group correctly answered that the disease stage was important in the treatment of lung cancer (group $1=73.23 \%$, group $2=82.35 \%$ ). The participants in group 1 repeated the same misconception in the previous question that the medical treatment for asthma and COPD were provided by thoracic surgeons $(67.6 \%, \mathrm{n}=48)$. This misconception was resolved in group $2(n=0)$, owing to further medical school education received by these students. The low rate of awareness of sympathectomy for regional hyperhidrosis in either group has been a warning sign to us, highlighting the need that this subject matter should be better emphasized in the thoracic surgery curriculum for the school of medicine students.

Because of the high number of students in medical schools, thoracic surgery education is mostly provided theoretically, resulting in inadequacies in practical training. No survey participants provided the correct answers to the fourth question that inquired the definitions of operation types in the area of thoracic surgery, supporting the observation about the practical training inadequacies. In both groups, the least known term was "videothoracoscopy" (group $1=12.67 \%$ ) (group $2=23.52 \%$ ), which can be associated with the recent introduction of this new method. A similar finding was reported by another study, in which specialist physicians in our country were surveyed about the types of thoracic surgery interventions. That study found that $27.2 \%$ of specialist physicians did not know the definition of videothoracoscopy precisely (2).
While $21(29.57 \%)$ participants in group 1 answered yes to the fifth question, which asked whether the participant would like to specialize in thoracic surgery, no participants in group 2 would like to specialize in this field of medicine. A survey study on 352 students from 32 medical schools across the United Kingdom reported that, of all survey participants, $10.8 \%$ wished to specialize in thoracic surgery; however, this rate was found as low as $4.7 \%$ among the $5^{\text {th }}$ grade medical school students (3). A similar figure was found by a study from the United States, reporting a rate of $6 \%(4)$.

In our research, the option "i am fond of surgery" was the most commonly selected rationale by the participants. The second most common rationale for the participant's preference was the low scores required to be accepted for thoracic surgery residency $(n=6)$. This rationale was followed by the third most common rationale that thoracic surgery would provide more satisfaction compared to other surgical branches $(n=5)$.

Regarding the rationale for disfavoring, the first-grade students most commonly selected the option that they would prefer a less risky field of specialty than thoracic surgery $(n=20)$. This rationale was followed by the one that the participant would decide based on the MSE/TUS scores $(n=14)$. The third most common rationale was the affinity of the participant for specialty areas of internal medicine $(n=12)$. In group 2, "a close interest in specialty areas of internal medicine $(n=28)$ " was preferred most commonly. This rationale was followed by the option that the participant would like to decide based on the MSE/TUS scores $(n=22)$. The third most commonly selected option was "the preference for a less risky area of specialty other 
than thoracic surgery" $(n=16)$. These results reveal that the performance anxiety about MSE (TUS), the recent increase in the number of malpractice file suits, and heavy penalties to physicians have affected the plans of medical students about specialization.

\section{Conclusion}

The results of this research demonstrated inadequacies in both secondary and higher education. These results suggest the likelihood of errors in the future when referring and consulting patients who presented to clinics other than thoracic surgery. Furthermore, we are of the opinion that the medical student's prioritization of MSE (TUS) scores and the attempts to avoid potential risks of thoracic surgery will unfavorably affect physicians and future medical practices further.

\section{Ethics}

Ethics Committee Approval: Our study was approved by the Local Ethics Committee (decision no: 2019/155). This study was conducted in compliance with the principles of the Declaration of Helsinki (version: B.10.4.ISM.4.06.68.48/184).

Informed Consent: Consent of partipiciant has been taken.

Peer-review: Externally peer-reviewed.

Financial Disclosure: The author declared that this study has received no financial support.

\section{References}

1. Yıldırım Ş, Metin B, Yıldırım E. Interests of Thoracic Surgery: A Questionnaire Study. Bozok Med J 2015;5(2):19-23.

2. Aktin B, Apilioğulları B, Esme H, Yoldaş T. An interview with specialist physicians: what are the interests of thoracic surgery? Turkish J Thorac Cardiov Surg 2012;20(4):840-842.

3. Preece R, Ben-David E, Rasul S, Yatham S. Are we losing future talent? A national survey of UK medical student interest and perceptions of cardiothoracic surgery. Interact Cardiovasc Thorac Surg 2018;27(4):525-529

4. Vaporciyan AA, Reed CE, Erikson C, Dill MJ, Carpenter AJ, Guleserian KJ, et al. Factors affecting interest in cardiothoracic surgery: survey of North American general surgery residents. J Thorac Cardiovasc Surg 2009;137(5):1054-1062. 